\title{
Why companies prefer applicants from non-immigrant families: investigating access to vocational training among low-qualified adolescents with an interlinked firm-applicant survey
}

Janina Söhn* (D)

*Correspondence: Janina.Soehn@sofi. uni-goettingen.de Soziologisches

Forschungsinstitut Göttingen (SOFI) an der Georg-AugustUniversität, Friedländer Weg 31, 37085 Göttingen, Germany

\begin{abstract}
In the German system of dual vocational training, in which companies recruit apprentices, graduates from low-level secondary schools (Hauptschule), and particularly those from immigrant families, are at a significant disadvantage regarding access to such apprenticeships. Previous qualitative studies have already pointed to the role of companies' recruiting criteria for mechanisms of indirect discrimination, e.g., their desire for smooth social interaction within the firm. This article builds on a standardized survey among companies to which low-skilled adolescents successfully or unsuccessfully applied for dual vocational training. The company data are matched with secondary longitudinal survey data on the same girls and boys. Which recruiting criteria put ethnic minorities at a disadvantage and hence indirectly facilitate ethnic discrimination? The theoretical approach considers (knowledge of) the immigration country's official language as both a functional requirement and a tool of hierarchical ethnic boundary making. In addition, concepts of social interaction within firms and respective norms as well as of homophily are subjected to an empirical test. Statistical results show that the below-average recruitment chances of applicants with a migration background are somewhat lower if companies stress a social fit criterion in their selection procedures. Furthermore, contrary to the initial hypothesis, ethnic minority youths are only substantially disadvantaged when applying to firms which consider the ability of verbal expression less crucial. Firms which consider this criterion very important may give applicants from immigrant families the chance to present themselves in a job interview and thus dispel ethnic stereotypes like the one that second-generation immigrant youths display serious language deficiencies.
\end{abstract}

Keywords: Dual vocational training, Apprenticeships, Ethnic minority, Secondgeneration immigrant, Low-level school education, Recruiting preferences, Recruiting decisions, Company survey the source, provide a link to the Creative Commons licence, and indicate if changes were made. The images or other third party material in this article are included in the article's Creative Commons licence, unless indicated otherwise in a credit line to the material. If material is not included in the article's Creative Commons licence and your intended use is not permitted by statutory regulation or exceeds the permitted use, you will need to obtain permission directly from the copyright holder. To view a copy of this licence, visit http://creativeco mmons.org/licenses/by/4.0/. 


\section{Introduction}

Germany is a prime example of a coordinated economy with a large segment of vocational educational training (VET) within the national education system. ${ }^{1}$ Companies are a major actor regarding the organization of apprenticeships in the dual VET system, which take place both on the job in a firm and in occupational schools. Young people striving for this qualification have to apply individually to companies that offer apprenticeships. It is the company-not vocational schools-that may choose among applicants. Hence, firms act as gatekeepers to such vocational training. This articles focuses on how such gatekeeping operates. The matching of company and trainee is subject to market mechanisms such as employee recruitment procedures. This logic of selection is characterized by the relation between supply and demand, by applicant queues with more or less favorable positions, and by the risk of discrimination based on ascriptive features like gender or ethnic background.

In legal terms, there are no preconditions regarding educational credentials-be it the kind of secondary school diploma or the average grade attained-with respect to most types of apprenticeships in Germany. In reality, however, this important transition in adolescents' life course from secondary school to occupational training very much depends on the kind of diploma that applicants graduate with (see, e.g., Autorengruppe Bildungsberichterstattung 2018; Baas and Philipps 2019; Protsch and Solga 2016; Erdmann 2016). Within the highly stratified secondary school system in Germany, graduates with a low-level secondary school diploma (Hauptschulabschluss) face severely lower chances of starting an apprenticeship than those with a mid-level school diploma (Realschulabschluss/Mittlere Reife) or a high-level school diploma (Abitur), which also allows access to tertiary education. Post-school qualification, including its level and occupational specialization, strongly influences employment opportunities, job quality, and financial gratification in their subsequent life course.

The kind of secondary-school diploma that applicants for dual VET can present to potential employers serves the latter as a signal for the applicant's human capital and learning capacity - to some extent a justified signal. ${ }^{2}$ Unequal treatment based on ascriptive characteristics, in contrast, is neither legitimate nor legal. In this regard, adolescents from immigrant families or-depending on the empirical operationalization-of non-native citizenship are disadvantaged in gaining access to VET in Germany (Autorengruppe Bildungsberichterstattung 2018; Beicht and Walden 2018, 2019; Hunkler 2016; BMBF 2019; see also various chapters in the edited volume by Scherr 2015). Similar ethnic disparities have been found in other countries with a strong dual VET system like Switzerland (Seibert et al. 2009). In addition to high bivariate correlations, these studies show that applicants from ethnic minorities face a higher risk of remaining without VET and having to resort to preparatory prevocational programs even when previous academic performance is statistically controlled

\footnotetext{
1 This article is based on a research project funded by the German Hans Böckler Stiftung (201-277-5). I am grateful for constructive comments by the two anonymous reviewers and by colleagues in this project and a related one, Bettina Kohlrausch, Maria Richter, Meike Baas, and Sophie Krug von Nidda, as well as for preceding data management and statistical results my analysis could built on.

2 While the average competence of students on the three tiers of secondary schools correspond to their structural hierarchy, there is a substantial overlap between high achievers in the lower-level schools compared to the low achievers in the higher ones (Autorengruppe Bildungsberichterstattung 2016: 94).
} 
for, i.e., when the studies account for the fact that ethnic minority students already have less opportunity to reach higher-level diplomas and better grades than peers of native parentage. Among youths with a migration background no longer attending school, $40 \%$ of 15 - to 19 -year-olds and $28 \%$ of 20 - to 24 -year-olds have at most a low-level secondary school diploma. These are substantially larger shares than among native peers (24 and 15\%, respectively; see Autorengruppe Bildungsberichterstattung: Tab. B5-5web, author's calculation).

This article focuses on applicants to dual VET who are multiply disadvantaged in terms of low-level secondary schools and ethnic minority status, and empirically investigates the firm-applicant linkage with regard to recruiting practices and results. As will be elaborated in the "Previous insights into ethnic and education-related disadvantages in VET" section, research has until now investigated ethnic disparities in VET on the side of either applicants or companies. This study uses a unique database that merges a survey on companies with one on applicants who graduated from low-level schools in the German regional state of Lower Saxony and applied successfully or unsuccessfully to the aforementioned companies.

In order to detect discrimination, several studies have used correspondence tests with fake applications [regarding apprenticeship in Germany, see Protsch (2017) with respect to organizational features and Protsch and Solga (2017) regarding discrimination based on immigrant status; regarding college students' internships in Germany, see Kaas and Manger (2012); on ethnic discrimination in the labor market, see Thijssen et al. (2019) for Germany compared to the Netherlands and Zschirnt (2019) for Switzerland]. In comparison to such field experiments, the data used here reflect a greater measure of external validity because they capture the real action of companies in terms of actual recruitment. Thus, this study can better answer the following research questions: to what extent do companies' recruiting preferences influence which types of graduates from low-level secondary schools they select for apprenticeship, and which graduates remain without vocational training? Which company preferences interact with the high risk of adolescents from immigrant families remaining without an apprenticeship?

Given that outright racist justifications for not recruiting ethnic minorities are illegal and (for many) socially unacceptable, indirect and less conscious forms of unequal treatment appear more likely. Qualitative studies using in-depth interviews with actors in companies responsible for hiring apprentices show how some of them voice concealed forms of ethnic prejudice. For instance, they refer to bad experiences with "foreign" apprentices even though it turns out later in the interview that they have never actually employed one but merely "heard" about trouble (Imdorf 2007; see also Schneider et al. 2015: 418 with regard to Turkish-origin applicants to German companies). As "Conceptual approaches to companies as gatekeepers in dual VET" section will argue, companies' preference for familiarity and homogeneity within their workforce as well as good German language skills-both a functional requirement and an ethno-national markermay act as indirect avenues leading to the overrepresentation of apprentices from native families. "Methods" section presents the database and operationalization. "Results and discussion" section reports the extent to which firms share stereotypical views on migrants and then tests two hypotheses empirically. "Conclusions" section summarizes the main findings and gives an outlook on future research and policy options. 


\section{Previous insights into ethnic and education-related disadvantages in VET}

Occupation-specific regulations, upon which German employer organizations, trade unions, and the government agree in regular consultations, do not include any minimum school qualifications as a precondition for apprenticeships in the dual VET system. ${ }^{3}$ Among the roughly 500,000 new apprentices in the dual system in 2016, 23.6\% had a low-level secondary school diploma, $47.4 \%$ a mid-level one, $22.8 \%$ a high-level one, and $5.1 \%$ no diploma or some other qualification (Autorengruppe Bildungsberichterstattung 2018: Tab. E1-2A). Over the last decades, the share of secondary school graduates with low-level degrees in dual VET has declined (Baas and Philipps 2019: 432). This partly reflects their shrinking share among students more generally, i.e., the educational expansion in favor of high-level secondary (and tertiary) education. But in addition, their relative chance of gaining access to VET compared to peers with higher education has decreased. This is to some extent due to the upscaling of tasks to be learned for specific vocational programs (Protsch 2013), but it is also due to the stigmatization of low-level school graduates as "unfit" for dual VET, independent of their actual performance measured by grades on the school-leaving diploma or by competence tests (Protsch and Solga 2016: 654; Autorengruppe Bildungsberichterstattung 2018: Table E1-9web).

The field of non-academic dual VET is de facto hierarchically stratified by the level of secondary school education (Protsch and Solga 2016: 642). In the upper-most and expanding segment with administrative, IT, and media-related occupations, only $3.8 \%$ of trainees have low-level or no school diplomas, whereas in the lowest segments with occupations in the crafts, construction, food trades, and care assistance, $60 \%$ have at most a low-level degree (Autorengruppe Bildungsberichterstattung 2016: 111). Many companies prefer not to recruit any apprentices rather than those from low-level schools.

The stratification of the VET system by school level is highly correlated with social and ethnic origins, as they are strong determinants for secondary school attainment in Germany. Yet there is only limited evidence that socio-economic origin still matters in the transition from school to VET once educational performance is taken into account (Beicht and Walden 2019: 42; see also Kohlrausch 2012: 262). In contrast to social inequalities, ethnic disparities have been severe for decades within the German VET sector: $35.9 \%$ of second-generation immigrants (i.e., German-born students of foreignborn parents) had to resort to prevocational programs in 2016, as did $44.1 \%$ of students who immigrated before age 6 and 41.8\% of those arriving at a later age (many of them probably refugees who came in the 2015/2016 refugee influx). Among peers of native parents, only $25.7 \%$ transitioned to preparatory programs and $58.3 \%$ to dual VET. The latter's share amounts to $45.4 \%$ among second-generation youths (Autorengruppe Bildungsberichterstattung 2018: 153-156, 2008: 140 for older results). These ethnic and/ or migration-related disadvantages persist when various education-related characteristics are statistically held constant (Autorengruppe Bildungsberichterstattung 2018:

\footnotetext{
${ }^{3}$ In other types of (solely) school-based vocational training, namely in the occupational fields of health and pre-school education (popular among women), students need at least a medium-level secondary school degree. For drop-outs from low-level secondary schools and for graduates from special schools for children with learning disabilities, chances of gaining access to VET are particularly low (Powell and Felkendorff 2008). School-based VET (21.7\% of first-year VET sector students in 2016) and preparatory prevocational programs (30.2\%) make up the two other segments of the German VET system apart from dual VET (48.1\%; see Autorengruppe Bildungsberichterstattung 2018: Figure E1-4A).
} 
Tab. E4-4web; Beicht and Walden 2018: 16; Diehl et al. 2009: 59). Further differentiating among applicants with a migration background, Beicht and Walden (2019:42) show that those whose parents immigrated from Turkey, the Middle East, or North Africa are at a particularly high risk of being discriminated against. Distinguishing between occupations, Schneider et al. (2015: 24) show with an experimental correspondence test that the rate of invitations to job interviews for applicants with Turkish sounding names was lower in the case of automobile mechatronics than in that of office administration, when compared with applications from native Germans.

Few studies have looked into intersectional inequalities regarding access to dual VET. According to Beicht and Walden (2019: 40), ethnic disparities are stronger among men than among women, and young men of Turkish or Arab origins have the overall lowest share among those entering dual VET (for a qualitative study on the school-to-training transitions of young second-generation women, see Schittenhelm 2005). Separate multivariate models for different subgroups show that only male applicants of immigrant origins do not significantly profit from a mid-level secondary school degree (Beicht and Walden 2019: 42). These results on ethnic disparities in access to dual VET clearly call for further explanations of companies' recruiting behavior.

\section{Conceptual approaches to companies as gatekeepers in dual VET}

Apart from below-average school attainment, two different dimensions of unequal treatment come into play when trying to explain the hurdles faced by ethnic minorities applying for dual VET: legal status as determined by the government and discrimination by companies. Especially young asylum seekers and refugees have a hard time getting access to firm-based vocational training even though legal restrictions have been loosened since 2016 (Söhn and Marquardsen 2017; Schreyer et al. 2015: 20). As firms employ apprentices in dual VET (which leads to similar rights as those of other employees), nonEuropean-Union citizens without permanent residence status-as a general rule-must get permission to work in order to begin an apprenticeship. Potential employers may feel reluctant to deal with immigration authorities or anticipate that the apprentice might have to leave the country in the course of training. Such factors, besides failing to obtain a working permit, play a role in firms not choosing applicants with foreign citizenship and with precarious legal status in particular. Yet the large majority of ethnic minority youths have German citizenship nowadays and have spent their whole lives in the German education system. Why do companies recruit these second-generation immigrants less often than applicants of native parentage?

For quite some time, sociology and economics have conceptualized firms as gatekeepers to employment in general. And choosing individuals as apprentices is only a sub-form of recruiting employees. The economist Arrow proposed the term statistical discrimination for cases when employers use their knowledge or their assumption about the average productivity of minorities (or regarding other ascriptive categories like gender) to conclude that they are on the "safer side" if they choose candidates from the majority instead. They use observable characteristics "as a surrogate for the unobservable characteristics which in fact causes the productivity differences" (Arrow 1998: 96). In the case of Germany, this could be a family name not "sounding German". Adding a photo to one's application is still the norm and makes some 
minorities visible at first sight. The research quoted above showed that employers put ethnic minority members at a disadvantage even if their school diploma and grades are comparable to those of ethnic majority peers. The fact that ethnic disparities remain rampant stands in contrast to the supposition of mainstream economics that discriminatory employers will be put out of business by non-discriminatory competitors, whose workforces are more productive (Arrow 1998: 95). The concept of statistical discrimination remains important, however, because the discriminating actor may think they act rationally (wanting to avoid less productive apprentices) without necessarily exhibiting ethnic prejudice per se. However, it remains hard to distinguish employers' "objective" information about the average productivity of any group from related forms of prejudice.

This also applies to a feature of the application process that is clearly related to migration and integration: competence in the official language of the immigration country. I would like to argue that German language skills play an ambiguous role in recruiting processes. On the one hand, they are an obvious functional requirement for smooth communication at the workplace and with clients, as is the role of language in immigrant integration more generally (Esser 2006). While deficient language skills are certainly a major obstacle for many newly immigrated individuals on the labor market, the issue is far from clear-cut in the case of the primarily secondgeneration applicants studied here. Students with immigrant parents indeed have below-average competence in reading and writing German (Autorengruppe Bildungsberichterstattung 2016: Tab. D6-6A), but studies on access to dual VET controlled for such competence or for grades in German (see above). Therefore, the second function of the German language, that of an ethno-national marker of difference and hierarchy, deserves further consideration.

Proficiency in the German language among immigrants and their descendants has long been a subject of public discourse in Germany. Numerous government regulations name learning German as an obligatory part of immigrants' integration effort (Buck 2011: 38-41). There is broad political consensus about German language skills as "the key to integration" (Gerdes and Bittlingmayer 2011: 121). With regard to the children of immigrant parents, public discourse regularly refers to the colloquial idea of a bilingual upbringing "gone wrong", or so-called double half-competence, which entails "insufficient" language skills in both German and the parental language (Riehl 2006: 22). Demanding good German language skills takes place in an asymmetrical power relation in which natives formulate this necessity and judge what is "sufficient". The often repeated call for learning German transports an implicit assumption that immigrants and their offspring do not try hard enough and generally do not reach sufficient levels of competence.

This also becomes apparent in the Swiss context, which bears much resemblance to Germany due to its large sector of dual VET. In Imdorf's (2007: 418) in-depth interviews of Swiss employers offering apprenticeships, they voiced concerns about bad knowledge of German (and of academic performance) and saw this as a major obstacle to choosing non-Swiss applicants. Assuming that human resources (HR) personnel may share the presumption that many ethnic minority youths lack sufficient German language skills, it seems plausible to expect that companies for which 
German language skills are a very important criterion for recruiting apprentices will be less inclined to employ applicants from migrant families than other firms, while for native applicants it does not matter how strongly companies support this selection criterion (Hypothesis 1).

Another line of argument pertains to a more encompassing notion of which applicant might fit well into the company's current workforce. The latter may include other apprentices, a person responsible for training, supervisors, or the business owners themselves in the case of small firms. In this regard, Arrow (1998: 95) dismisses the possibility of discrimination "due to discriminatory tastes of other employees" too easily. The socio-psychological concept of homophily, "the principle that a contact between similar people occurs at a higher rate than among dissimilar people" (McPherson et al. 2001: 416), has been productively applied to empirical research on the recruiting process. The often unconscious preference for people who share a similar social background-including socialization associated with ascriptive categories like gender and ethnicity-may result in a workforce of unbalanced composition, e.g., women and ethnic minorities being underrepresented (Roth 2004: 434; McPherson et al. 2001).

Without explicitly building on the concept of homophily, the sociologist Imdorf (2010) makes a comparable distinction between three different social spheres as well as corresponding norms and conventions of behavior in any workplace. Referring to Boltanski and Thevenot's (2006) concept of cites, social spheres with different forms of coordination and values, Imdorf (2010: 87-88) differentiates, first, the "industrial world of the firm, the fabrication of consumer goods or the provision of services"; second, the world of the market, including interaction with clients; and third, the "domestic world" of social interaction among the workforce, on which the following arguments focus. With the rational goal of a well-run business in mind, companies seek to keep horizontal and vertical social relationships free of conflict. Some ethnic majority business owners perceive the potential for minorities to disturb smooth and familiar ways of social interaction. In Imdorf's (2007: 418) study, rather than explaining directly why they rather not train ethnic minority members (beyond the language and qualification argument), interviewed bosses of smaller firms underlined the need for an apprentice to fit into the Swiss tradition of family-owned businesses, anticipating conflicts along ethnic or linguistic lines among the staff. ${ }^{4}$ This "gut feeling" approach, when applied to the final recruiting of apprentices, rationalizes de facto biased personnel selection because its emotion-based screening enables and accelerates such decisions "under conditions of time pressure and uncertainty" (Imdorf 2010: 100). One way to overcome prejudice against various social groups is to offer longer internships in which students can actually show their work-related and social skills before applying for a full apprenticeship at the same firm (Solga and Kohlrausch 2013). Yet such internships are still the exception. Overall, companies that stress that apprentices should fit well into the domestic world are expected to choose VET applicants from immigrant families less often than other firms, while this selection criterion is not decisive for native applicants (Hypothesis 2).

${ }^{4}$ Similarly, they voiced the fear that customers with whom the apprentices would interact might react badly to their ethnic background and avoid the firm in the future (Imdorf 2010: 99). 


\section{Methods}

This study builds on two unique interlinked standardized surveys, one among companies and one among adolescents who applied to those firms for apprenticeships. The former was carried out in 2012 among owners or human-resource managers of firms in the (West) German regional state of Lower Saxony. The topics covered, e.g., ways of recruiting apprentices; criteria for evaluating written applications, job interviews, and overall selection criteria and preferences; and general attitudes towards applicants with lowlevel secondary education, from ethnic minorities, or of female gender. Furthermore, the questionnaire inquired about basic structural information concerning the company and the interviewees themselves. This company survey was then merged with a longitudinal panel survey on applicants stemming from previous research projects. These former projects started out with three evaluation studies of 8th graders in selected low-level secondary schools divided into experiment classes (with special support like long-term or multiple internships until 9th grade) and control classes (Solga and Kohlrausch 2013). ${ }^{5}$ After the first interview in their classrooms, these teenagers were repeatedly interviewed (CATI) over an average span of 6 years between 2007 and 2013. In fall 2010, the interviewees were asked to give the names and contact details of the companies to which they had sent an application for apprenticeship. These companies were then identified and asked to participate in the survey on their recruitment practices. Finally, the data of the firm survey could be interlinked to those applicants of the panel survey who had applied to these companies either successfully or unsuccessfully (information on applications submitted to non-interviewed firms is not available, though). This procedure results in a unique dataset with a dually nested structure: at times, more than one interviewed graduate applied to an interviewed firm, and some participating adolescents applied to several companies that took part in the survey. The 446 applicants and 345 companies form 596 applicant-company dyads in the final dataset. Table 1 gives an overview of the sample structure.

Given this methodological project history, one has to keep in mind that neither the samples of the 8th graders nor of the applicants finally studied or of companies were based on randomized selection. Still, the company survey covers a large variety of businesses: $47 \%$ of the companies are located in the service sector, $28 \%$ in the crafts, and $22 \%$ in the industrial sector. ${ }^{6} 31 \%$ of them had up to 25 employees, $39 \%$ between 26 and 250 employees, and the remaining $29 \%$ more than 250 employees. ${ }^{7}$ Companies in the service sector are underrepresented in the survey by 33 percentage points compared to the Lower Saxonian average and applicants in this sector by 20 percentage points compared to the respective state-wide share of employees (Landesamt für Statistik Niedersachsen 2019: 7; author's calculation). This is plausible given that low-qualified school graduates have easier access to the crafts and face insurmountable hurdles to the higher

\footnotetext{
${ }^{5}$ In the sample used here, $36 \%$ of the applicants attended an "experimental" class with extra support. Although these students had on average lower grades than those of the control classes (implying a negative selection bias), having been a student of one or the other did not significantly impact the probability of being employed by an interviewed firm. Unfortunately, the study does not contain information on whether a person who participated in a long-term internship as part of the "treatment" applied for a full apprenticeship at the very same firm or at different companies.

${ }^{6}$ No differentiation by occupational field beyond this sectorial one is feasible.

7 Large firms like Volkswagen, Continental, or TUI have their headquarters in Lower Saxony.
} 
Table 1 Sample structure: distribution of applicants across firms and vice versa

\begin{tabular}{llllcc}
\hline & \multicolumn{2}{l}{ Firms applied to per applicant } & & \multicolumn{2}{c}{ Applications per firm } \\
\cline { 2 - 3 } \cline { 5 - 6 } & $\mathbf{n}$ & \% (column) & & $\mathbf{n}$ & \% (column) \\
\hline 1 & 454 & 76.2 & 503 & 84.4 \\
2 & 109 & 18.3 & 57 & 9.6 \\
3 to 4 & 33 & 5.5 & 18 & 3.0 \\
5 to 11 & - & - & 18 & 3.0 \\
Total & 596 & 100.0 & 596 & 100.0 \\
\hline
\end{tabular}

echelons of the service sector. Furthermore, the distribution of applicants across firm size is roughly the same as that of employees in this state (ibid.: 8).

Within the group of applicants, 121 interviewed graduates successfully applied at a firm participating in the survey. Among the remaining individuals who were not recruited by any of these firms, the longitudinal data show that 283 of them began VET at other companies (not interviewed) while 42 remained wholly unsuccessful in their applications. However, longitudinal research has shown that starting an apprenticeship does not equal its successful completion. On average, one in four apprenticeships ends prematurely (Autorengruppe Bildungsberichterstattung 2016: 111), either for good or in order to start VET at a different company. Given this insight and the low case number of those 42 unsuccessful individuals mentioned above, this study combines the available information on recruitment with previous results of the project. Kohlrausch and Richter (2016: 159) calculated a sequence and cluster analysis of the educational-vocational trajectories for all participants in the panel study, including the girls and boys in the firm-applicant sample used here. Two longitudinal clusters imply failed educational trajectories. (1) Those whose trajectories are caught in an institutional waiting loop: after an average of 21 months in compensatory programs, only a minority finally got access to vocational training. (2) Young men and women in a dead-end situation: after an average of 13 months in such prevocational training, they transitioned into unqualified employment. Interviewees who belonged to one of those two clusters were re-categorized regarding the dependent variables of this study. Seventeen applicants initially belonging to those "successful at interviewed firm" and 51 with a "successful application at firm not interviewed" were re-categorized as having an "unsuccessful school-to-VET transition". This re-categorization leaves 110 individuals in the unsuccessful subgroup, $25 \%$ of the sample. In the final version of the dependent variable, youths "successful at interviewed firm" and those successful at a company not interviewed comprise 23 and $52 \%$, respectively.

Even though all interviewees attended a low-level secondary school in 8th grade, they vary with regard to the degree they finally graduated with. Sixty-one percent graduated after 9th grade, most of them having attained a low-level school diploma (nine individuals were left without any degree); 39\% continued to attend 10th grade, most of them having attained a medium-level school degree (though 20 only attained a so-called "extended" low-level diploma). However, the kind of school diploma turned out to have no statistically significant effect on the outcome (and accordingly does not serve as a 
control variable $)^{8}$-despite ample evidence to the contrary in studies with representative data, as referred to in the previous sections. Therefore, the following clarification is called for: the data used here do not allow a systematic comparison between graduates from low- and medium-level secondary schools. Rather, even the students who achieved mid-level school degrees attained them at low-level secondary schools (for this regulation in Lower Saxony, see MK 2019). As a consequence, it is still a low-level school which issued the school-leaving certificate-and having the name of such a school on one's diploma might serve as a negative, stigmatizing signal in the recruiting process.

In terms of ethnic disparities, $25 \%$ of the graduates in the dataset are identifiably from immigrant families, i.e., at least one parent born abroad; $58 \%$ are of native parentage. I crosschecked that interviewees with insufficient information do not vary significantly from those with immigrant parents with regard to bivariate distributions across the dependent variable and key independent ones. In order to avoid an extra missing category in an already small sample, those 77 individuals without sufficient information are re-categorized as (probably) from immigrant families. ${ }^{9}$ In the year 2011, 23.4\% of Lower Saxony's population under 20 had this kind of "migration background" (Niedersachsen 2014: 11), a share which is plausibly higher in low-level schools given ethnic inequalities in secondary education.

In terms of the key predictor variables, the survey question of how important the "ability of expression in terms of language" (sprachliches Ausdrucksvermögen) is as a criterion for recruitment operationalizes the importance firms place on German language skills (Hypothesis 1). The item "the apprentice fits well into the team" (author's translation) serves to operationalize the notion of socially fitting into the firm's "domestic world" (Hypothesis 2). In both instances, the answer category "very important" versus "important/rather unimportant/very unimportant" discriminates best (and only a minority of 19 and 4\% respectively judged the language and team item as rather/very unimportant). Both selection criteria are only expected to exert a significant impact on the applicants' success in interaction with an ethnic minority status. As the two recruiting criteria proved indeed to be of no influence among applicants of native heritage, this latter group serves as the reference to ethnic minority youths who applied to firms agreeing strongly versus less strongly with the two statements. ${ }^{10}$

In terms of individual characteristics serving as control variables, the multivariate analysis considers participation in none versus at least one prevocational preparatory program. With $53 \%$ having attended at least one prevocational preparatory program, the sample shows a slightly higher share than graduates from low-level secondary schools on the federal level around the same time (47\% in 2010; Autorengruppe Bildungsberichterstattung 2018: Tab. E1-9web, author's calculation). Social origin is identified by the distinction of whether or not at least one parent is in full-time employment (versus part-time employment or unemployment), i.e., an indicator of the parents' labor market

\footnotetext{
8 This has been checked for potential suppressor effects regarding the outcomes of short verbal and figural cognitive tests, grades in mathematics and in German, as well as attending a school class with extra internships, as mentioned above.

9 Sensitivity analyses showed that the effects presented later were minimally stronger if those with missing information on migration were left out of the regression model.

10 This simplified interaction term with three categories is preferable to calculating a main effect plus an interaction effect which presumes a metric scale and is often wrongly interpreted (Berry et al. 2010).
} 
integration versus exclusion. While previous studies used the level of parental education (Beicht and Walden 2019; Solga and Kohlrausch 2013), parental employment status proves to exert more predictive power than the latter in my analysis. However, neither social origins nor the applicants' type of school-leaving degree per se exert a significant impact on their success. Rather, the model needs to differentiate the effect of having a low-level school diploma on recruitment by the employment status of the apprentices' parents and thus includes a simplified interaction term of those two variables. Applicants with mid-level school diplomas, for whom parental employment status was not relevant for recruitment, serve as the reference category. Company-level control variables which have a statistically significant impact in the full model comprise the information about whether the company recruited apprentices with the support of an online job database and whether the firm considered a "personal recommendation" of the applicant to be a very important selection criterion.

As the quantitative results are not representative in a strict sense, the following chapter refrains from showing bivariate results and instead focuses on multivariate analysis. ${ }^{11}$ In the multinomial logistic regression suitable for a target variable with three categories, one has to keep in mind that the effects of firm-level predictors regarding the subcategory "successful at non interviewed company" are ambiguous in their causal plausibility and are thus not interpreted in a substantial manner. Regarding the effects of applicantlevel factors, however, this subgroup proves to be more similar to those adolescents who successfully applied to an interviewed firm. ${ }^{12}$

\section{Results and discussion}

Before turning to the hypotheses on indirect mechanisms of ethnic discrimination, let us consider the possibility of measuring ethnic stereotypes and more specifically their potential direct effect on recruiting decisions. One section of the company survey asks the interviewees to state how far they agree with general statements which do not refer to themselves or their company in a straightforward way. Depending on the specific statements, differing shares of interviewed firms agreed that adolescents from immigrant families have "trouble" with the German language (43\%), cause problems in interaction with clients $(28 \%)$, are negative for social cohesion among apprentices $(4 \%)$, or that they attract clients of the same ethnic origin (13\%). A majority (64\%) disagreed with the statement that most clients have no problem when a girl wears a headscarf. But there are no significant relationships between these five items und recruitment results; further, there is U-shaped relationship between the former and an index of social desirability. Hence, a simplistic relationship between openly expressed ethnic prejudice and discriminatory behavior cannot explain the full extent of ethnic inequalities in recruitment.

Let us turn to the results concerning the first hypothesis about an indirect mechanism of ethnic discrimination — that companies which deem the ability of verbal expression a

\footnotetext{
${ }^{11}$ Due to this non-random sampling, specifying levels of significance does not make sense statistically, strictly speaking. However, as significance levels still give an idea of the "importance" of an effect (if the data were representative), this article refers to them in the text and Table 2. In addition, see the comparative discussion of predictive power and effect sizes between different independent variables.

12 An alternative binominal logistic regression (not shown) which excludes applicants beginning an apprenticeship at a non-interviewed firm yields results very similar to the multinomial ones presented here.
} 


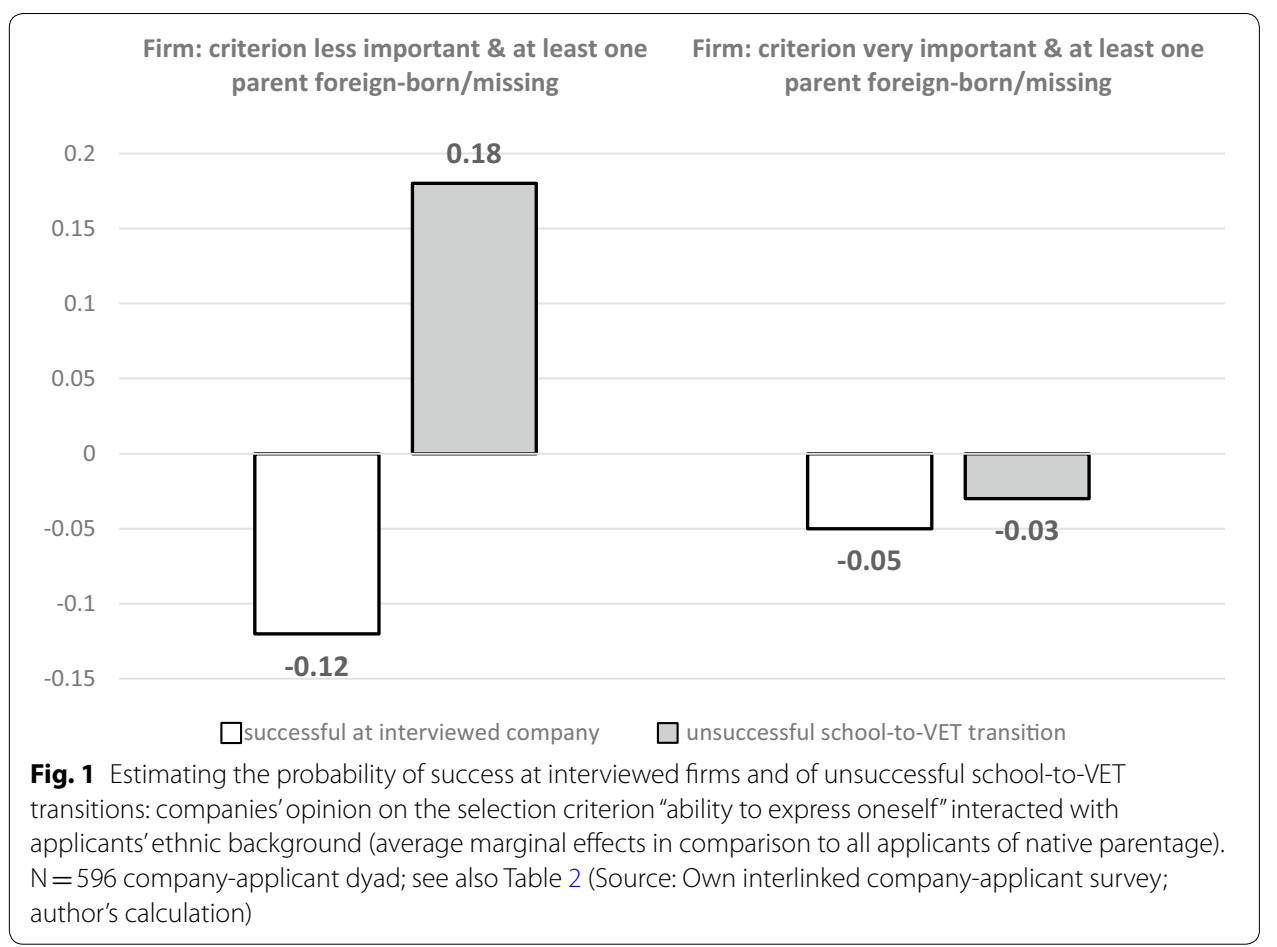

very important selection criterion are less inclined than other firms to employ applicants from immigrant families as apprentices. The survey item used here does not include the term "German". Hence, ethnicity is not salient. Yet it is self-evident that this ability (without specifying whether orally or in writing) can only refer to German. Figure 1 depicts the regression results in the form of average marginal effects (AME), also called average predicted comparisons, i.e., the estimated difference of percentage points between the key predictor's subcategories with respect to the probability of falling into each category of the dependent variable. Figure 1 and Table 2 report the estimated difference of percentage points - net effects of the full models - between (a) ethnic minority adolescents applying to firms which regarded this criterion as very important and (b) ethnic minority adolescents applying to firms which did not think so-in both cases compared to the average native applicant as the reference category.

The results speak against Hypothesis 1: school graduates from immigrant families who applied to a company which considered the ability to verbally express oneself very important had about the same chance of success as peers of native parentage. The small effects did not reach statistical significance (right side of Fig. 1). In sharp contrast, the probability of being recruited for ethnic minority adolescents who applied to other interviewed firms (which did not deem this criterion to be very important) was 12 percentage points lower (white bar on left side) and their risk of experiencing an altogether unsuccessful school-to-VET transition 18 percentage points higher (gray bar on left side) than applicants from native families. In terms of the full ethnic penalty, one should think of these two results as belonging together.

How are these disparities to be explained? It is not the case that the compared groups of companies differ in their general opinion about ethnic minority adolescents' 


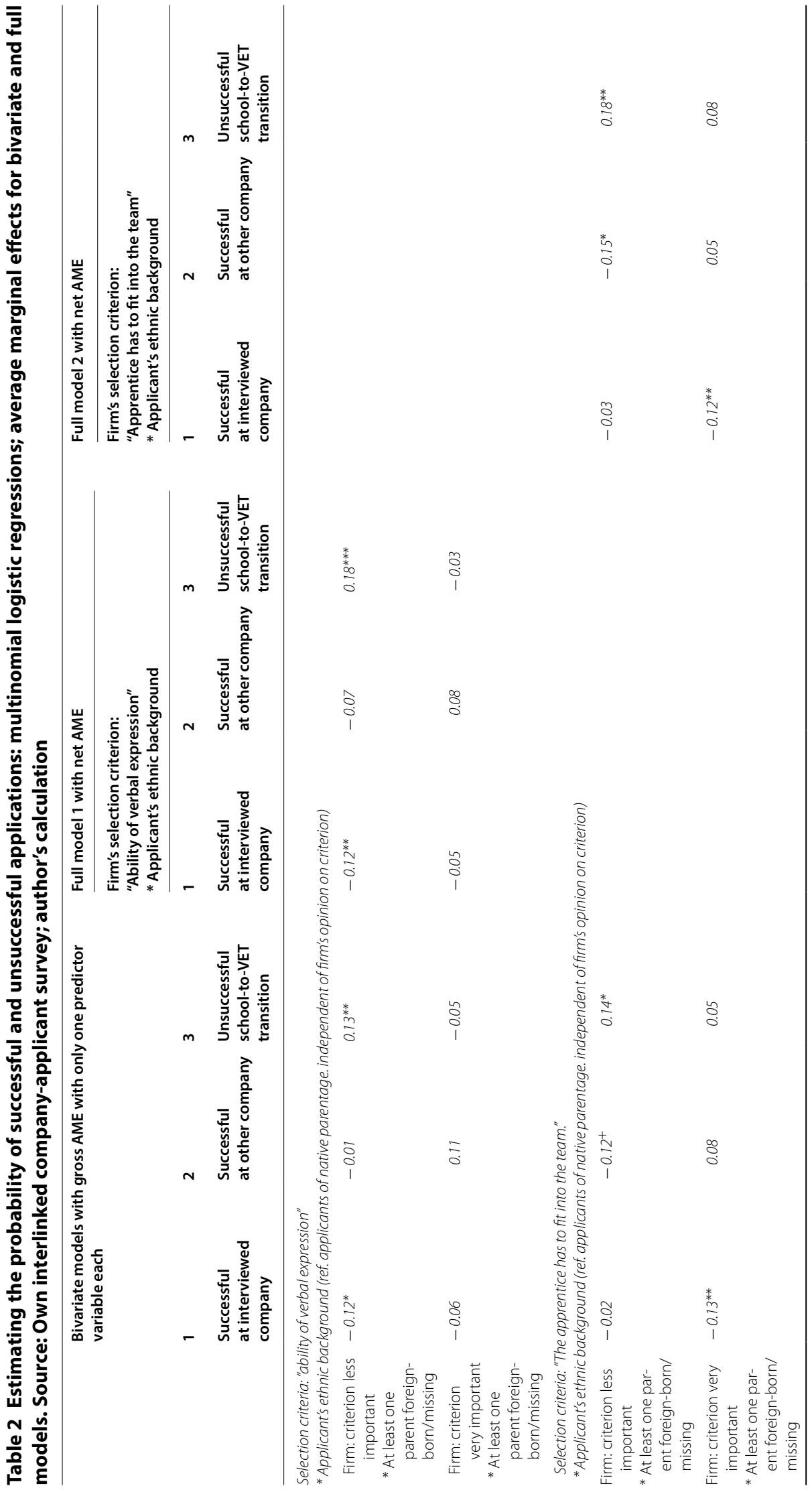




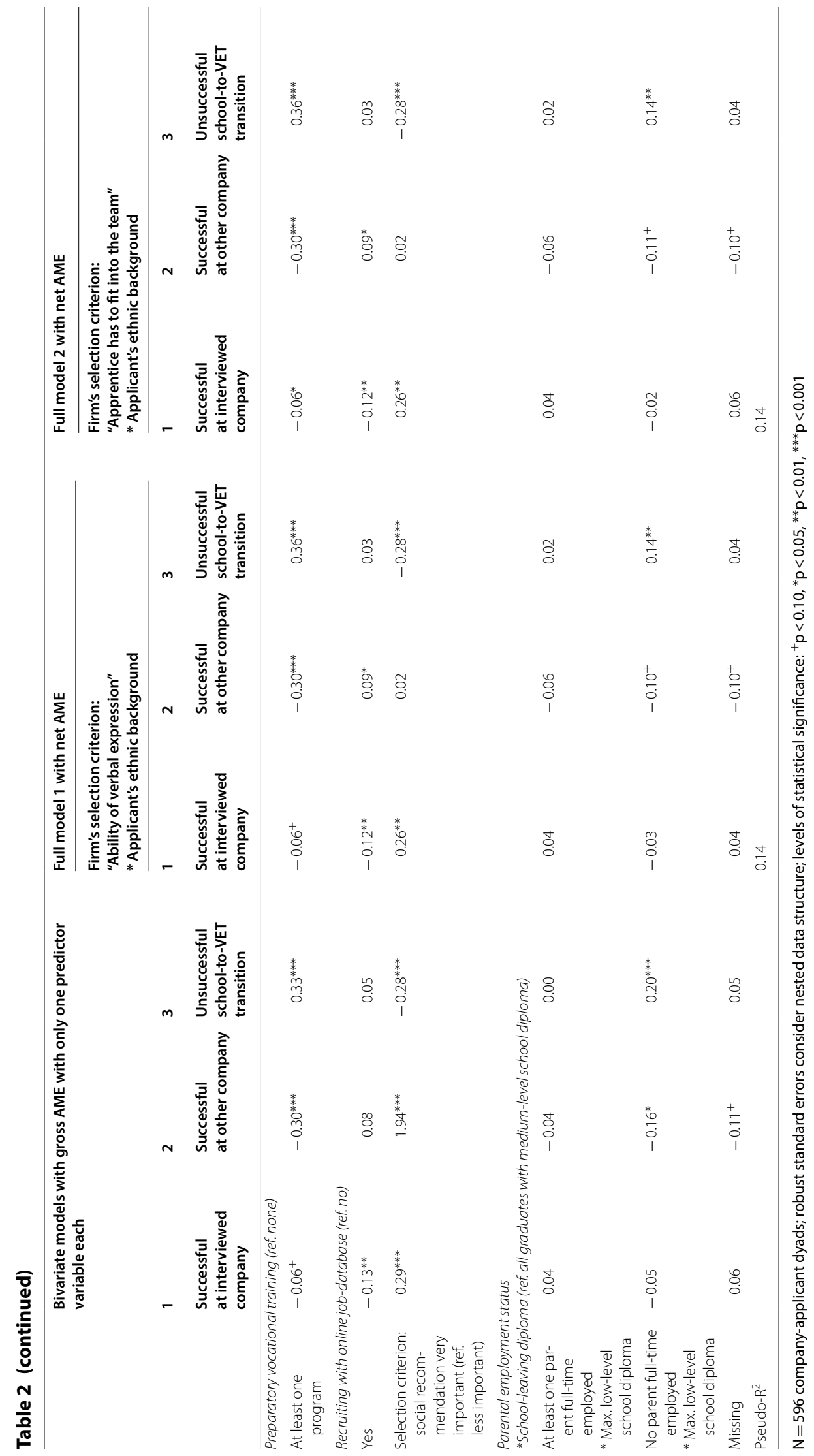




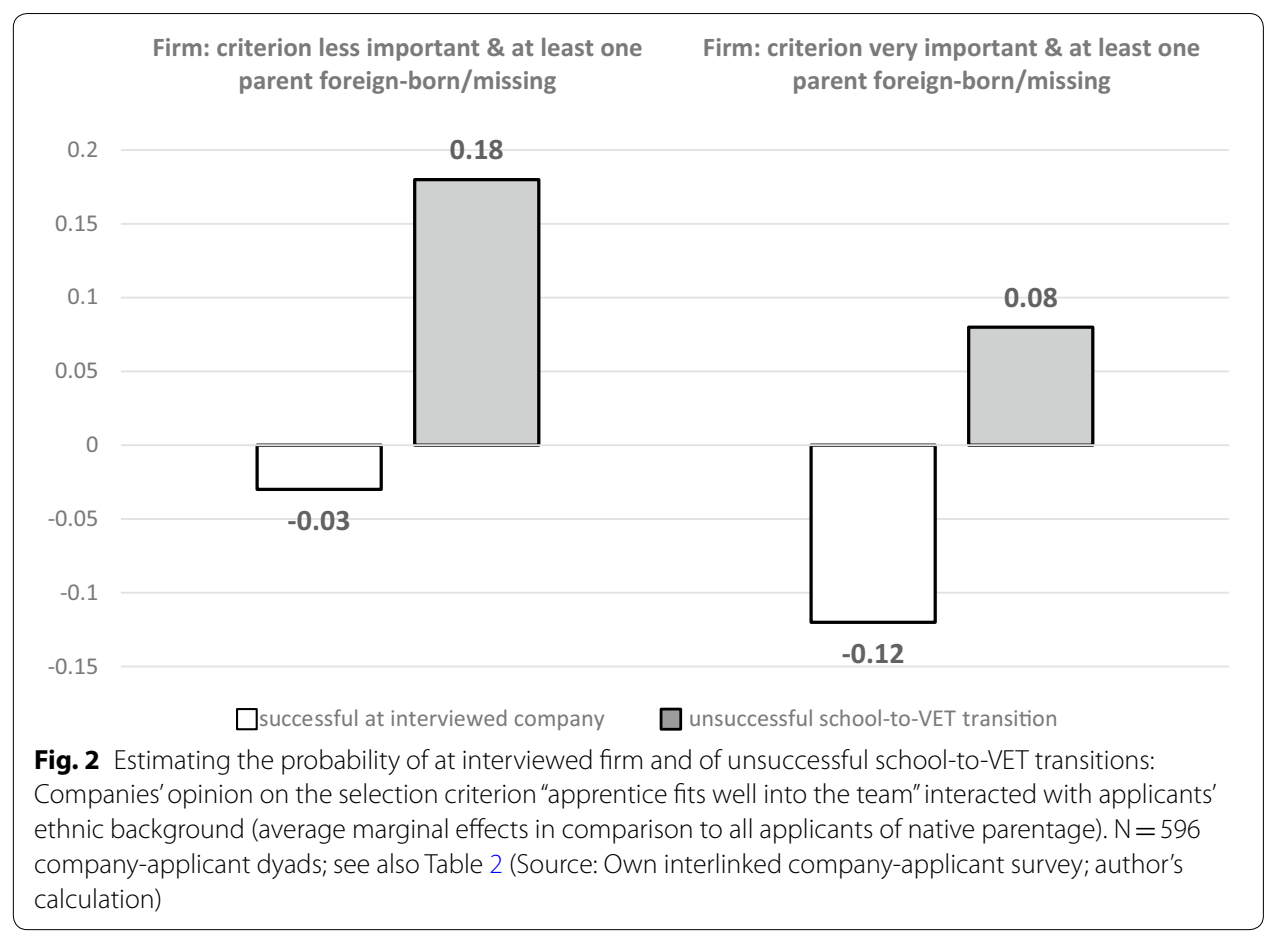

(assumed) deficiencies in German, given their answers to the respective question mentioned above. A probable causal mechanism could be that firms which regard this linguistic capacity as very important had a closer look at the style and immaculateness of the written applications and invited applicants of native and immigrant origin who fulfilled their minimum standard. Subsequently, when ethnic minority applicants had the opportunity to present themselves in an interview and the HR personal could confirm that their verbal expression was proficient, the applicants had the same chance to become an apprentice as their native peers. Hence, these companies might have actually evaluated this language-specific criterion, i.e., the functional side of language, in a meritocratic way. The other firms might have just assumed linguistic deficiencies (and possibly others too) without evaluating them rigorously.

Next, this study analyses the extent to which concepts of otherness versus assumed familiarity within the firm's domestic world result in ethnic disparities by way of a selection criterion concerning how well apprentices to fit into the team socially. Here, again, the question whether the interviewed company thought that this criterion was very important or not is irrelevant for native applicants. In line with Hypothesis 2, the results show that this distinction makes a difference for applicants from immigrant families as compared to ethnic majority candidates to some extent.

The probability that ethnic minority applicants were chosen by an interviewed firm was an estimated average of 12 percentage points lower than that of natives if they applied to a company which strongly agreed that it was important for an apprentice to fit into the team (white bar on right side of Fig. 2). In addition, a complementary model (see Table 3 in Appendix) in which this ethnic minority sub-group served as the reference 
group indicates that the difference to the other peers from immigrant families is statistically significant as well, confirming the assumed interaction of migration background and the company's strong preference for social fit. However, regarding the risk of experiencing an unsuccessful trajectory from school to VET, the picture is less clear. Among firms which deemed this criterion very important, applicants of non-native parentage face a risk of unsuccessful school-VET transitions 8 percentage points (gray bar on right side) higher than that of natives, without this difference reaching statistical significance. Regarding firms which thought otherwise, the ethnic minority-majority gap was 18 percentage points (gray bar on left side) and significant (contrary to Hypothesis 2). Nevertheless, the difference between both immigrant groups did not turn out to reach statistical significance when one of them is the reference group (Table 3 in Appendix) instead of natives (Table 2).Taken together, these effects do-only-partly support Hypothesis $2 .^{13}$ This does not automatically mean that the respective mechanism of indirect discrimination found by qualitative studies is irrelevant, but that ethnic homophily preferences may also influence the recruitment practices of firm survey respondents that did not characterize the social fit criterion as very important.

The two company-level factors studied here (ability of expression and social fit) correlate only slightly. The businesses for which the ability of expression was a very important selection criterion had above-average shares of immigrants in their workforces (26 percentage points above average), which probably contributed to unbiased recruiting behavior. They belonged more often to the service sector (24 percentage points above the average)-maybe because communication with clients plays a more important role here than for occupations within the industrial and craft sectors. Among companies that did not consider the social fit criterion to be very important, firms in the crafts-the large majority with smaller numbers of employees-were less common (10 percentage points below average) and those in the industrial sector more common (20 percentage points above average); the share of immigrants among employees was more often above average (19 percentage points) than among companies which deemed social fit very important. These structural factors by themselves, however, did not exert a significant impact on the applicants' success in this particular sample.

Table 2 contains gross and net effects. Gross effects (first three columns) stem from models with only one predictor or its subcategories taken together. Net effects are reflected in the full model, in which all predictor variables shown are included. Comparing gross and net effects reveals that the two key predictors hardly change or even increase slightly when controlled for the other factors. This means the results shown are stable and statistically significant despite the relatively small number of cases.

One should bear in mind that the predictive power of two key predictors (Pseudo- $\mathrm{R}^{2}$ amounting to 0.011 in bivariate models, respectively) is modest compared to that of the control variable with by far the highest predictive power, previous participation in prevocational programs (Pseudo- $R^{2}=0.092$ ), though it is similar to that of other controls.

13 This confirms preliminary results from the same dataset by Krug von Nidda (2019: 28), who had modelled the target and predictor variables somewhat different though. 
The AMEs of the two key predictors show effect sizes that are sometimes roughly similar to those of prevocational training and other times not even half their size.

Besides the strong effect of having attended at least one preparatory program on the probability of an unsuccessful trajectory, control variables reveal the following associations: when applicants attained only a low-level school degree and came from a parental home characterized by economic exclusion, their risk of an unsuccessful school-to-VET transition rose by an estimated average of 14 percentage points. ${ }^{14} \mathrm{~A}$ stronger interaction effect not presented here is between parental economic background and migration background, which is also worth exploring with a larger, representative sample. In terms of influential business characteristics, considering personal recommendations a very important selection criterion raised the probability of a successful application sharply (despite the rather small number of cases). Obviously, such recommendations enable applicants to circumvent the strong stigma around low-level school graduates. Furthermore, using an online database for the recruiting process had a consistently negative influence on the probability of being selected by the interviewed firms. The businesses with online recruiting tools tended to be larger, belong to the industrial sector more often than to the craft sector, have less low-qualified employees, and be more sought after by applicants than the other firms-a result that corresponds well to Protsch's (Protsch 2017: 594) experimentally designed study.

\section{Conclusions}

This article has used a unique set of interlinked firm-applicant data in order to investigate crucial mechanisms of indirect ethnic discrimination in dual VET in Germany. The analysis yielded evidence of how ethnic bias in recruiting behavior works through the connection between companies' recruiting preferences and the ascribed features of ethnic minority applicants. Meanwhile, multivariate models held important educational signals like previous participation in prevocational programs constant.

Previous qualitative findings (Imdorf 2007, 2010) suggest that firms prefer harmony and familiarity in the domestic world of the company. In order to avoid creating conflict or prematurely ending an apprenticeship, thus spoiling their investment in the "wrong" applicants, companies are believed to shy away from those of foreign parentage as a "preventative measure". The quantitative firm-applicant survey, however, found only some evidence that a firm's relative emphasis on how well applicants "fit into the team" might have an influence on ethnic minority adolescents' chances of being recruited. Future research with a higher number of cases and better possibilities to differentiate should test whether the assumed effect is particularly relevant for ethnic minority youths with a high risk of ethno-racial stigmatization, such as those identifiable by a "non-German" name of Turkish or Arab origin, darker skin color, or a head scarf.

Second, companies which highly value the selection criterion of good verbal expression may organize their recruitment process in a way that gives applicants from immigrant families the opportunity to prove, e.g., in job interviews, that their German is proficient, counter to prejudiced assumptions about immigrants and second generation

${ }^{14}$ See Kohlrausch (2012: 265) for a similar effect of low parental qualification. 
youths. As to the companies for which linguistic abilities are somewhat less important, it seems plausible that prejudice regarding ethnic minority graduates' linguistic skills feeds into a larger skepticism about them, which in turn translates into below-average training rates. When asked about problems with "weaker" apprentices, only $5 \%$ of German firms who had had ethnic minority apprentices named language-related obstacles in the survey of Enggruber and Rützel (2015: 41). Furthermore, in the survey analyzed here, only $2 \%$ of companies that had previously trained apprentices with a migration background would not do this again.

In terms of methodological limitations, the major drawbacks of the database used here are the-for quantitative analysis-small number of cases as well as the lack of formal representativeness. Hence, it remains unclear in a number of instances whether the lack of statistically significant correlations between potentially influential factors and the ethnic minority-majority gap is only due to the sample size or to a systematic similarity between groups. Still, interlinking the panel survey on applicants with the company survey is a very suitable design for tackling research questions like those of this article. The external validity is clearly higher than experimental studies which can follow the success of "fake" applications only to the point of an invitation to a job interview but not to the applicants' actual employment, as this study could. However, in terms of methodological lessons for the future, it seems advisable to add such a company survey to an already existing representative large-scale study with a special focus on school-toVET-and-work transitions such as the German National Educational Panel Study (Starting Cohort 9th Grade). ${ }^{15}$ Furthermore, future research may try to measure the quality of written applications (in terms of, e.g., typos and adequate language style) and its effect on invitations to job interviews and on actual recruitment, as many schools and support programs teach students how to write "good" applications.

The analysis revealed that many recruiting preferences measured in the survey show little variance between firms. This renders them statistically unsuitable as predictors even though very common selection criteria like the candidate's reliability and motivation (Krug von Nidda 2019: 27) - and especially their perception by the company-surely do play an important part in the recruiting process. Apart from structural characteristics of the company (e.g., the apprenticeship supply-and-demand ratio and economic sector), information like the company's recruitment of candidates through traineeships or the selection criterion of the "general impression" given by written applications did not hold as significant predictors in multivariate estimation models. The fact that many criteria named as important for selecting apprentices do not discriminate between applicants from the ethnic majority and minorities is mirrored in another company survey: Enggruber and Rützel (2015: 37) also find no significant difference between firms which did or did not have apprentices from immigrant families during the preceding 5 years-neither with regard to selection criteria nor to suggestions for improving the quality and success rate of dual VET in general. Some items which were thought to potentially put ethnic minority applicants at a disadvantage-like "gut feeling" (author's translation from the questionnaire)-show no bivariate correlation to speak of. The wording of items is obviously important; it must be 
sensitive to social norms which discourage HR personnel from voicing opinions that sound outright non-meritocratic or unprofessional. These methodological problems in standardized surveys suggest that qualitative research, which can go deeper, is still needed in this field. Yet, as Imdorf (2010: 98) has suggested, the next step-however difficult to realize-should be participant observation in job interviews or in meetings when HR personnel discuss interviewed candidates.

Given that almost all companies which have already trained apprentices from immigrant families would not mind doing it again, those without such experience should be encouraged to give it a try. Demographic aging and the expansion of tertiary education will further decrease the number of applicants for VET. The shorter the line of applicants, the more willing some firms might become to "try out" an ethnic minority apprentice for the first time and hence break the ice for others later on. The results presented here suggest that inviting such candidates and listening to them might already contribute to diffusing potential reservations on the firm's part that oral German language skills could be deficient.

Furthermore, important actors in the political arena like the German Trade Union confederation and the Federal Anti-Discrimination Agency have been demanding for quite some time that at least large- and mid-sized companies should adopt anonymized application procedures (FAZ 2019)-otherwise still the exception in Germany. Such recruiting practices tend to improve equal opportunity for various at-risk groups, including individuals with a migration background (for the evaluation of such a pilot project among large German firms, see Krause et al. 2012: 9-10). Most ethnic minority applicants for VET have gone through the German school system from kindergarten onwards and would probably profit from anonymized application procedures, though immigrants' foreign educational career (like that of recent refugees) can hardly be disguised in a CV, pointing to the limitations of such a tool. Finally, regional states should invest more resources into the educational opportunities of immigrant children and the children of immigrants in primary and secondary education in order to boost their chances of accessing dual VET.

\section{Abbreviations}

VET: Vocational educational training; HR: Human resources.

\section{Acknowledgements}

I am grateful for constructive comments by the two anonymous reviewers and by colleagues in this project and a related one, Bettina Kohlrausch, Maria Richter, Meike Baas, and Sophie Krug von Nidda, as well as for preceding data management and statistical results my analysis could built on.

\section{Authors' contributions}

The author is responsible for the conceptualization and writing of the manuscript as well as for the methodolgy applied in the formal analysis. The author read and approved the final manuscript.

\section{Authors' information}

Dr. Janina Söhn is a sociologist and senior researcher at the Soziologische Forschungsinstitut (SOFI [Sociological Research Institute]) associated with Göttingen University, Germany. With a general focus on social inequality, she has published on different aspects of immigrant integration including secondary and post-school education, legal status und integration policies as well as on immigrants' and natives' employment careers and retirement.

\section{Funding}

The analysis and interpretation of data as well as writing the manuscript was supported by the German Hans Böckler Stiftung (201-277-5) 
Competing interests

The authors declare that they have no competing interests.

\section{Appendix}

See Table 3.

Received: 9 October 2019 Accepted: 18 May 2020

Published online: 30 May 2020

Table 3 Alternative reference categories when estimating the probability of successful and unsuccessful applications: multinomial logistic regressions; average marginal effects for full models. Source: Own interlinked company-applicant survey; author's calculation

\begin{tabular}{|c|c|c|c|c|c|c|}
\hline & \multicolumn{3}{|c|}{ Full model 1 with net AME } & \multicolumn{3}{|c|}{ Full model 2 with net AME } \\
\hline & \multicolumn{3}{|c|}{$\begin{array}{l}\text { Firm's selection criterion: } \\
\text { "Ability of verbal expression" } \\
\text { *Applicant's ethnic background }\end{array}$} & \multicolumn{3}{|c|}{$\begin{array}{l}\text { Firm's selection criterion: } \\
\text { "Apprentice has to fit into the team." } \\
\text { *Applicant's ethnic background }\end{array}$} \\
\hline & 1 & 2 & 3 & 1 & 2 & 3 \\
\hline & $\begin{array}{l}\text { Successful } \\
\text { at interviewed } \\
\text { company }\end{array}$ & $\begin{array}{l}\text { Successful } \\
\text { at other } \\
\text { company }\end{array}$ & $\begin{array}{l}\text { Unsuccessful } \\
\text { school- } \\
\text { to-VET } \\
\text { transition }\end{array}$ & $\begin{array}{l}\text { Successful } \\
\text { at interviewed } \\
\text { company }\end{array}$ & $\begin{array}{l}\text { Successful } \\
\text { at other } \\
\text { company }\end{array}$ & $\begin{array}{l}\text { Unsuccessful } \\
\text { school- } \\
\text { to-VET } \\
\text { transition }\end{array}$ \\
\hline \multicolumn{7}{|c|}{$\begin{array}{l}\text { Selection criteria: "ability of verbal expression" } \\
\text { "Applicant's ethnic background (ref. Firm: crite }\end{array}$} \\
\hline $\begin{array}{l}\text { Applicants } \\
\text { of native } \\
\text { parentage. } \\
\text { inde- } \\
\text { pendent } \\
\text { of firm's } \\
\text { opinion on } \\
\text { criterion }\end{array}$ & $0.11^{* *}$ & 0.06 & $-0.17^{* * *}$ & & & \\
\hline $\begin{array}{l}\text { Firm: crite- } \\
\text { rion very } \\
\text { important } \\
\text { * At least } \\
\text { one parent } \\
\text { foreign- } \\
\text { born/miss- } \\
\text { ing }\end{array}$ & 0.06 & 0.10 & $-0.16^{* *}$ & & & \\
\hline \multicolumn{7}{|c|}{$\begin{array}{l}\text { Selection criteria: "The apprentice has to fit into the team." } \\
\text { *Applicant's ethnic background (ref. Firm: criterion less important * at least one parent foreign-born/missing) }\end{array}$} \\
\hline $\begin{array}{l}\text { Applicants } \\
\text { of native } \\
\text { parentage. } \\
\text { Inde- } \\
\text { pendent } \\
\text { of firm's } \\
\text { opinion on } \\
\text { criterion }\end{array}$ & & & & 0.03 & $0.14^{*}$ & $-0.17^{* *}$ \\
\hline $\begin{array}{l}\text { Firm: crite- } \\
\text { rion very } \\
\text { important } \\
\text { * At least } \\
\text { one parent } \\
\text { foreign- } \\
\text { born/miss- } \\
\text { ing }\end{array}$ & & & & $-0.12^{*}$ & $0.20^{* *}$ & -0.08 \\
\hline
\end{tabular}

$\mathrm{N}=596$ company-applicant dyads; control variables are the same as in the full models in Table 2; robust standard errors consider nested data structure; levels of statistical significance: ${ }^{+} p<0.10,{ }^{*} p<0.05,{ }^{* *} p<0.01,{ }^{* * *} p<0.001$ 


\section{References}

Arrow KJ (1998) What has economics to say about racial discrimination? J Econ Perspect 12(2):91-100

Autorengruppe Bildungsberichterstattung (2008) Bildung in Deutschland 2008. Ein indikatorengestützter Bericht mit einer Analyse zu Übergängen im Anschluss an den Sekundarbereich I. Bertelsmann, Bielefeld

Autorengruppe Bildungsberichterstattung (2016) Bildung in Deutschland 2016. Ein indikatorengestützter Bericht mit einer Analyse zu Bildung und Migration. Bertelsmann, Bielefeld

Autorengruppe Bildungsberichterstattung (2018) Bildung in Deutschland 2018. Ein indikatorengestützter Bericht mit einer Analyse zu Wirkungen und Erträgen von Bildung. Bertelsmann, Bielefeld

Baas M, Philipps V (2019) Über Ausbildung in Arbeit? Verläufe gering gebildeter Jugendlicher. In: Forschungsverbund Sozioökonomische Berichterstattung (ed) Berichterstattung zur sozioökonomischen Entwicklung in Deutschland. Exklusive Teilhabe - ungenutzte Chancen. Dritter Bericht, Bertelsmann, Gütersloh, pp 411-446

Beicht U, Walden G (2018) Übergänge nicht studienberechtigter Schulabgänger/-innen mit Migrationshintergrund in vollqualifizierende Ausbildung. BIBB-Report 6|2018, Bundesinstitut für Berufsbildung (BIBB), Bonn

Beicht U, Walden G (2019) Der Einfluss von Migrationshintergrund, sozialer Herkunft und Geschlecht auf den Übergang nicht studienberechtigter Schulabgänger/-innen in berufliche Ausbildung. BIBB Wissenschaftliche Diskussionspapiere Heft 198, BBIB, Bonn

Berry WD, DeMeritt JHR, Esarey J (2010) Testing for interaction in binary logit and probit models: is a product term essential? Am J Polit Sci 54(1):48-266

BMBF (Bundesministerium für Bildung und Forschung) (2019) Berufsbildungsbericht 2019, Berlin

Boltanski L, Thevenot L (2006) On justification: economies of worth. Princeton University Press, Princeton

Buck E (2011) Asymmetrische Gemeinschaft. "Integration" als leerer Signifikant im Zugehörigkeitsdiskurs Deutschlands und Großbritanniens. Sociol Int 49(1):29-52

Diehl C, Friedrich M, Hall A (2009) Jugendliche ausländischer Herkunft beim Übergang in die Berufsausbildung: Vom Wollen, Können und Dürfen. Zeitschrift für Soziologie 38(1):48-67

Enggruber R, Rützel J (2015) Berufsausbildung junger Menschen mit Migrationshintergrund. Eine repräsentative Befragung von Betrieben. Bertelsmann Stiftung, Gütersloh

Erdmann N (2016) Erfolgreiche Wege bildungsbenachteiligter Jugendlicher in dualen Ausbildungen - Rekonstruktionen zu Erfolgsbedingungen aus biographieanalytischer Perspektive. In: van Dausien B, et al (eds) Bildungswege. Biographien zwischen Teilhabe und Ausgrenzung. Frankfurt a.M., Campus, pp 333-361

Esser H (2006) Sprache und Integration. Die sozialen Bedingungen und Folgen des Spracherwerbs von Migranten. Campus, Frankfurt

Frankfurter Allgemeine Zeitung (FAZ) (2019) Unternehmen haben bei anonymen Bewerbungen noch Luft nach oben. https://www.faz.net/einspruch/beruf-und-ausbildung/antidiskriminierungsstelle-unternehmen-haben-bei-anony men-bewerbungen-luft-nach-oben-16604321.html. Accessed 5 Feb 2020

Gerdes J, Bittlingmayer UH (2011) Assimilations und Wissensgesellschaft. Bildungsgesteuerte Integrationsimperative im deutschen parteipolitischen Diskurs seit den Debatten um das Zuwanderungsgesetz. Sociol Int 49(1):03-138

Hunkler C (2016) Ethnische Unterschiede beim Zugang zu beruflicher Ausbildung. In: Diehl C et al (eds) Ethnische Ungleichheiten im Bildungsverlauf. Mechanismen, Befunde, Debatten. Springer, Wiesbaden, pp 597-641

Imdorf C (2007) Individuelle oder organisationale Ressourcen als Determinanten des Bildungserfolgs? Organisatorischer Problemlösungsbedarf als Motor sozialer Ungleichheit. Swiss I Sociol 33(3):407-423

Imdorf C (2010) Emotions in the hiring procedure: How'gut feelings' rationalize personnel selection decisions. In: Sieben B, Wettergren Ä (eds) Emotionalizing rrganizations and organizing emotions. Palgrave Macmillan, Houndmitls, pp 94-105

Kaas L, Manger C (2012) Ethnic discrimination in Germany's labour market: a field experiment. German Econ Rev 13(1):1-20

Kohlrausch B (2012) Betriebe als Gatekeeper. Sozialer Fortschritt 61(10):257-265

Kohlrausch B, Richter M (2016) Was fördert die nachhaltige Integration von Hauptschüler/linnen in den Ausbildungsmarkt? In: Arbeit. Zeitschrift für Arbeitsforschung, Arbeitsgestaltung und Arbeitspolitik, 25(3-4):147-168

Krause A, Rinne U, Zimmermann KF (2012) Anonymous job applications in Europe. IZA J Eur Labor Stud 1(5):1-24

Krug von Nidda S (2019) Welchen Einfluss haben betriebliche Selektionskriterien auf den Bewerbungserfolg von Jugendlichen mit Migrationshintergrund? Berufsbildung in Wissenschaft und Praxis 48(1):25-29

Landesamt für Statistik Niedersachsen (2014) Menschen mit Migrationshintergrund in Niedersachsen. Ergebnisse des Zensus 2011 auf regionaler Ebene. Hannover

Landesamt für Statistik Niedersachsen (2019) Regionale Strukturdaten der Betriebe. Auswertungen aus dem Unternehmensregister, Hannover

McPherson M, Smith-Lovin L, Cook JM (2001) Birds of a feather: homophily in social networks. Ann Rev Sociol 27:415-444

MK (Niedersächsisches Kultusministerium) (2019) Hauptschule. https://www.mk.niedersachsen.de/startseite/schule/ unsere_schulen/allgemein_bildende_schulen/hauptschule/hauptschule-6423.html. Accessed 18 July 2019

Powell JJW, Felkendorff K (2008) Transitions of people with disabilities beyond secondary education in Austria, Germany, and Switzerland. Background report prepared for the Organisation for Economic Co-operation and Development (OECD), Berlin/Zürich

Protsch P (2013) Höhere Anforderungen in der beruflichen Erstausbildung. WSI-Mitteilungen 66(1):15-22

Protsch P (2017) Getting a foot in the door: how organisational characteristics shape recruitment decisions in the dual apprenticeship system. J Educ Work 30(6):585-598

Protsch P, Solga H (2016) The social stratification of the German VET system. J Educ Work 29(6):637-661

Protsch P, Solga H (2017) Going across Europe for an apprenticeship? A factorial survey experiment on employers' hiring preferences in Germany. J Eur Soc Policy 27(4):387-399

Riehl CM (2006) Aspekte von Mehrsprachigkeit: Formen, Vorteile, Bedeutung. In: Becker-Mrotzek M et al (eds) Kölner Beiträge zur Sprachdidaktik. Duisburg, Gilles \& Francke, pp 15-23

Roth LM (2004) The social psychology of tokenism: status and homophily processes on Wall Street. Sociol Perspect 47(2):189-214 
Scherr A (ed) (2015) Diskriminierung in der beruflichen Bildung. Beltz Juventa, Weinheim

Schittenhelm K (2005) Primäre und sekundäre Effekte kultureller Praktiken. Der Ausbildungseinstieg junger Migrantinnen im interkulturellen Vergleich. Kölner Zeitschrift für Socziologie und Sozialpsychologie 57(4):691-715

Schneider J, Yemane R, Wienmann M (2015) Diskriminierung am Ausbildungsmarkt. Ausmaß, Ursachen und Handlungsperspektiven. Sachverständigenrat deutscher Stiftungen für Integration und Migration, Berlin

Schreyer F, Bauer A, Kohn K-HP (2015) Betriebliche Ausbildung von Geduldeten. Für den Arbeitsmarkt ein Gewinn, für die jungen Fluchtmigranten eine Chance. IAB Kurzbericht 1/2015, Nürnberg

Seibert H, Hupka-Brunner S, Imdorf C (2009) Wie Ausbildungssysteme Chancen verteilen. Berufsbildungschancen und ethnische Herkunft in Deutschland und der Schweiz unter Berücksichtigung des regionalen Verhältnisses von betrieblichen und schulischen Ausbildungen. Kölner Zeitschrift für Soziol und Sozialpsychol 61(4):595-620

Söhn J, Marquardsen K (2017) Erfolgsfaktoren für die Integration von Flüchtlingen. Forschungsbericht 484. Bundesministerium für Arbeit und Soziales, Berlin

Solga H, Kohlrausch B (2013) How low-achieving German Youth beat the odds and gain access to vocational traininginsights from within-group variation. Eur Sociol Rev 29(5):1068-1082

Thijssen L, Lancee B, Veit S, Yemane R (2019) Discrimination against Turkish minorities in Germany and the Netherlands: field experimental evidence on the effect of diagnostic information on labour market outcomes. J Ethn Migr Stud. https://doi.org/10.1080/1369183×.2019.1622793

Zschirnt $E$ (2019) Evidence of hiring discrimination against the second generation: results from a correspondence test in the Swiss labour market. J Int Migr Integr. https://doi.org/10.1007/s12134-019-00664-1

\section{Publisher's Note}

Springer Nature remains neutral with regard to jurisdictional claims in published maps and institutional affiliations.

\section{Submit your manuscript to a SpringerOpen ${ }^{\circ}$ journal and benefit from:}

- Convenient online submission

Rigorous peer review

- Open access: articles freely available online

- High visibility within the field

- Retaining the copyright to your article

Submit your next manuscript at $\mathbf{s p r i n g e r o p e n . c o m ~}$ 